\title{
Cleavage of C3 by Neutral Proteases from Granulocytes in Pleural Empyema
}

\author{
S. Suter, U. E. Nydegger, L. Roux, and \\ F. A. Waldvogel
}

From the Departments of Medicine, Pediatrics, and

Microbiology, University Hospital, Geneva, Switzerland

\begin{abstract}
The possibility of direct inactivation of $\mathrm{C} 3$ by granular enzymes from polymorphonuclear leukocytes (PMNLs) in pleural empyema was examined. As a group, pleural empyema from 10 patients with purulent effusions and a positive bacteriologic culture cleaved significantly more ${ }^{125}$ I-labeled C3 bound to Sepharose $(18.4 \% \pm 7.3 \%)$ than did 19 sterile pleural effusions $(2.4 \% \pm 0.9 \% ; P<<0.001)$ and sonicates from bacterial strains commonly found in empyema $(1.4 \% \pm 0.2 \%)$. Granular enzymes from $7 \times 10^{6}$ PMNLs cleaved $78.5 \%$ of ${ }^{125}$ I-labeled C3 bound to Sepharose. When proteolysis of ${ }^{125}$ I-labeled C3 after incubation with pleural empyema or PMNL granular enzymes was examined with polyacrylamide gel electrophoresis, breakdown products were similar. Granulocyte elastase-like activity was detected in four samples of pleural empyema. Granulocyte elastase inhibitors, as well as $10 \%$ human serum, effectively suppressed cleavage of $\mathrm{C} 3$ and elastase-like activity. In pleural empyemas, granular enzymes from PMNLs, especially elastase, apparently contribute to low complement-mediated opsonic activity by direct inactivation of $\mathrm{C} 3$.
\end{abstract}

Pleural empyema is a closed-space infection defined by the simultaneous presence of large numbers of live microorganisms and polymorphonuclear leukocytes (PMNLs). The disease is further characterized by its chronic evolution and its poor response to medical and sometimes even surgical therapy.

Work from our laboratory [1] has shown that the persistence of live microorganisms despite the presence of large numbers of PMNLs in pleural empyemas can be partially explained by a marked decrease in complement-mediated opsonic activity in culture-positive pleural effusions. This deficiency in opsonic activity was further shown to be accompanied by the local generation of increased amounts of $\mathrm{C} 3 \mathrm{~d}$, the inactive breakdown product of $\mathrm{C} 3$.

Serum complement is of major importance in the humoral immune response to pyogenic infections, and $\mathrm{C} 3$ is currently viewed as the target molecule of both the classical and the alternative pathways of complement activation [1-3]. Its ac-

Received for publication March 10, 1981, and in revised form June 22, 1981.

This work was supported in part by grant no. 3.836-0.79 from the Swiss National Research Foundation.

We thank Drs. M. Baggiolini and B. Dewald for advice, suggestions, and revision of the manuscript and F. Michaud for secretarial assistance.

Please address requests for reprints to Dr. F. A. Waldvogel, Department of Medicine, University Hospital, 1211 Geneva 4, Switzerland. tivation leads to the production of the biologically active fragment $\mathrm{C} 3 \mathrm{~b}$, and the coating of microorganisms with $\mathrm{C} 3 \mathrm{~b}$ promotes their recognition by PMNLs. Activation proceeds through the cleavage of native $\mathrm{C} 3$ by either the classical $(\mathrm{C} \overline{42})$ or the alternative $(\mathrm{C} 3 \mathrm{~b}, \mathrm{Bb})$ pathway convertase of $\mathrm{C} 3$ or both $[2,3]$. Recently it has been shown in vitro [4-8] that $\mathrm{C} 3$, as well as $\mathrm{C} 5$, can be split by complement-unrelated enzymes, such as purified neutral proteases from PMNLs. These reports have shown that the purified granular enzymes elastase, collagenase, and cathepsin G can act on $\mathrm{C} 3$ and $\mathrm{C} 5$ by splitting small fragments similar in size to $\mathrm{C} 3 \mathrm{a}$ and $\mathrm{C} 5 \mathrm{a}$ from the native molecules. Because these enzymes, especially elastase, act on a broad spectrum of substrates [9-12], ${ }^{1}$ it is conceivable that they could split C3 extensively and thus generate inactive breakdown products. Such a mechanism has already been demonstrated in vitro [8] and could account for our observations of low complement-mediated opsonic activity, low complement levels, and high levels of C3d in empyema [1]. We therefore tried to demonstrate C3-cleaving activity in pleural empyema using a reproducible in vitro test with purified, radiolabeled C3 covalently bound to Sepharose as a substrate.

\footnotetext{
I W. Schmidt, "Neutrale Proteasen aus menschlichen Leukozyten: Isolierung, charakterisierung und biologische Wirkungen," inaugural-dissertation, Fachbereich Chemie der Philipps-Universität Marburg/Lahn, Federal Republic of Germany, 1975, p. 66.
} 
Table 1. Characteristics of 10 patients with pleural effusions and positive bacteriologic cultures (empyema) in group 1.

\begin{tabular}{|c|c|c|c|c|c|}
\hline Patient no. & $\begin{array}{l}\text { Sex, age } \\
\text { (in years) }\end{array}$ & $\begin{array}{l}\text { Associated } \\
\text { disease }\end{array}$ & Bacteria cultured & $\begin{array}{c}\text { Protein concentration } \\
\text { ( }(\mathrm{g} / \text { /iter })\end{array}$ & $\begin{array}{c}\text { No. of } \\
\text { leukocytes/ } \mu\end{array}$ \\
\hline 1 & $\mathrm{M}, 51$ & Alcoholism & Peptococcus, Eubacterium lentum & 8 & 320,000 \\
\hline 2 & M, 57 & $\begin{array}{l}\text { Carcinoma of the } \\
\text { esophagus }\end{array}$ & $\begin{array}{l}\text { Bacteroides melaninogenicus, } \\
\text { Pseudomonas aeruginosa, } \\
\text { Streptococcus faecalis }\end{array}$ & 9 & 340,000 \\
\hline 3 & $F, 66$ & $\begin{array}{l}\text { Inactive pulmonary } \\
\text { tuberculosis }\end{array}$ & B. melaninogenicus & 36 & 190,000 \\
\hline 4 & $M, 60$ & None identified & $\begin{array}{l}\text { Peptococcus, Peptostreptococcus, } \\
\quad \text { Fusobacterium, B. melaninogenicus }\end{array}$ & 40 & 336,000 \\
\hline 5 & $\mathrm{M}, 43$ & None identified & $\begin{array}{l}\text { P. aeruginosa, Streptococcus, } \\
\text { Fusobacterium, B. melaninogenicus }\end{array}$ & 28 & 62,000 \\
\hline 6 & M, 26 & Teratoseminoma & Klebsiella pneumoniae & 46 & 1,350 \\
\hline 7 & M, 26 & None identified & Peptococcus, Fusobacterium & 40 & 100,000 \\
\hline 8 & $\mathrm{M}, 71$ & None identified & Streptococcus pneumoniae & 33 & 34,000 \\
\hline 9 & M, 57 & Alcoholism & Peptostreptococcus & 29 & 110,000 \\
\hline 10 & $\mathrm{M}, 20$ & Multiple trauma & Staphylococcus aureus & 30 & 300,000 \\
\hline
\end{tabular}

\section{Patients and Methods}

Patients. Twenty-nine patients hospitalized with pleural effusions at the University Hospital, Geneva, Switzerland, were divided into two groups.

Group 1 (empyemas) consisted of 10 patients with purulent effusions and a positive bacteriologic culture. Information about these patients and the bacteriologic results are presented in table 1. Associated diagnoses included alcoholism, inactive pulmonary tuberculosis, carcinoma of the esophagus, and multiple trauma. The mean age of the patients was 50 years (range, 20-71 years). Their pleural fluid had a mean protein concentration of $30 \pm 4 \mathrm{~g} /$ liter and a mean leukocyte count of $172,000 \pm 40,000$ cells $/ \mu \mathrm{l}$.

Group 2 (culture-negative effusions) consisted of 19 patients with pleural effusions for whom bacteriologic cultures were negative. Eight patients had parapneumonic effusions accompanying acute pneumonia. The diagnosis of pneumonia was established by clinical findings, appropriate cultures of sputum and/or blood, and chest roentgenograms. Six patients had pleural effusions drained after surgery for multiple trauma, coronary heart disease, mitral valve replacement, or carcinoma of the lung or the esophagus. Three other patients had metastatic cancer with pleural effusions, and two patients had transudates associated with congestive heart failure. Their mean age was 54 years (range, 32-91 years). The mean protein concentration in their pleural effusions was $32 \pm 3 \mathrm{~g} /$ liter, and the mean leukocyte count was $2,175 \pm 1,030$ cells $/ \mu$ l. The leukocyte counts in the two groups were significantly different $(P<<0.001)$.

Collection of pleural fluids. Thirty-nine samples of pleural fluid were collected from these 29 patients. Each sample was processed within 1 $\mathrm{hr}$ of thoracocentesis and was separated into two specimens: one was immediately mixed with EDTA (final concentration, $20 \mathrm{~mm}$ ) and the other was processed without additive. They were centrifuged (Heraeus-Christ, Osterode, Federal Republic of Germany) at $1,000 \mathrm{~g}$ for $10 \mathrm{~min}$; the supernatants were separated from the sediment, frozen immediately, and stored at $-70 \mathrm{C}$ until used. Leukocyte counts and protein concentrations were determined before centrifugation.

Preparation of granular enzymes from PMNLs. Blood freshly obtained from adult volunteers was treated with heparin (45 units/ml). PMNLs were isolated by Ficoll-Hypaque centrifugation and subsequent dextran sedimentation [13]. In some preparations Ficoll-Hypaque centrifugation was omitted because the contaminating lymphocytes and monocytes did not modify the enzymatic activity measured in our tests. PMNLs were washed three times with $0.9 \% \mathrm{NaCl}$, and contaminating red blood cells were removed by hypotonic lysis (addition of $9 \mathrm{ml}$ of ice-cold distilled water for $30 \mathrm{sec}$ and reconstitution of isotonicity by the 
addition of $3 \mathrm{ml}$ of $0.6 \mathrm{M} \mathrm{KCl}$ ). The resulting cell pellet was resuspended in $0.2 \mathrm{M}$ sucrose, and the cell concentration was adjusted to $10^{8} / \mathrm{ml}$. All subsequent steps were carried out in the cold (4 C). The cell suspension was homogenized (Braun, Melsungen, Federal Republic of Germany) at $1,500 \mathrm{rpm}$ for $5 \mathrm{~min}$, and cellular debris was removed by centrifugation at $12,500 \mathrm{~g}$ for $10 \mathrm{~min}$. The supernatant was used for the isolation of granules according to the method of Baggiolini [14]. The supernatant was centrifuged at $12,500 \mathrm{~g}$ for $20 \mathrm{~min}$ in an ultracentrifuge (model L5-65; Beckman Instruments, Palo Alto, Calif.), and the resulting pellet was extracted with $0.2 \mathrm{M}$ acetate, $\mathrm{pH} 4.4$, at $4 \mathrm{C}$ for $2 \mathrm{hr}$ with gentle stirring. The precipitated proteins were removed by ultracentrifugation at $100,000 \mathrm{~g}$ for $30 \mathrm{~min}$. The supernatant (volume, $5 \mathrm{ml}$ ) containing the granular enzymes was stored at $-70 \mathrm{C}$ in small aliquots and neutralized to $\mathrm{pH} 7.0$ with $\mathrm{NaOH}$ before use. The enzymatic activity of different batches extracted from $450 \mathrm{ml}$ of blood varied over a twofold range.

Purification of human $C 3$ and preparation of ${ }^{125}$ I-labeled C3 bound to Sepharose. C3 from human plasma was purified to homogeneity using the method of Tack and Prahl [15]. It was labeled with ${ }^{125}$ I (Radiochemical Centre, Amersham, England) by the chloramine-T method [16]. About $1.5 \times 10^{7} \mathrm{cpm}$ were incorporated into $10 \mu \mathrm{g}$ of purified C3. Labeled C3 was coupled to cyanogen bromide-activated Sepharose 4B (Pharmacia Fine Chemicals, Uppsala, Sweden).

Assessment of C3-cleaving activity. ${ }^{125} \mathrm{I}-$ labeled C3 bound to Sepharose was washed with Dulbecco's phosphate-buffered saline, pH 7.3, without $\mathrm{Ca}^{++}$or $\mathrm{Mg}^{++}$to remove unbound radioactivity. Samples of ${ }^{125}$ I-labeled C3 bound to Sepharose corresponding to $1.5 \times 10^{6} \mathrm{cpm}$, determined by counting in a gamma counter (Beckman), were incubated at $37 \mathrm{C}$ with EDTA-mixed supernatants of pleural effusions, with granular enzymes, or with bacterial sonicates and their culture supernatants. Aliquots were drawn at timed intervals over $9 \mathrm{hr}$, and ${ }^{125}$ I-labeled C3 cleaved from Sepharose was separated from uncleaved material by centrifugation at $8,000 \mathrm{~g}$ for $10 \mathrm{~min}$. Cleavage of $\mathrm{C} 3$ was expressed as percentage of cpm in the supernatant divided by the $\mathrm{cpm}$ of the total sample.

Measurement of elastase-like activity. Elastase-like activity was tested with the artificial substrate succinyl-Ala-Ala-Pro-7-amino-4-methyl- coumarin (TGP 928), a gift from M. Baggiolini, Wander Research Institute, Bern, Switzerland. Granulocyte elastase selectively cleaves the 7amino-4-methyl-coumarin part of the molecule, which has an extinction coefficient of 12,200 at $360 \mathrm{~nm}$. Because the specificity of this substrate has been tested with purified enzymes and is not demonstrable in our biologic system, the term "elastase-like" was chosen to describe its activity. Various samples of pleural fluid, granular enzymes, or bacterial sonicates were mixed with TGP 928 (final concentration, $10^{-3} \mathrm{M}$ ) in $0.5 \mathrm{M}$

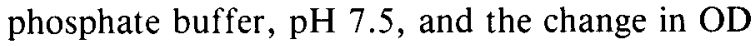
at $360 \mathrm{~nm}$ in a spectrophotometer (Beckman) was observed over a 4-min period. Over this interval, the enzymatic reaction was linear for all samples tested. Enzymatic activity was expressed as the increase in OD over 4 min.

Demonstration of proteolysis by culturepositive pleural effusions of ${ }^{125}$ I-labeled $C 3$ by polyacrylamide gel electrophoresis. ${ }^{125} \mathrm{I}$-labeled C3 was combined with either the EDTA-mixed supernatant of a culture-positive effusion from patient no. 2 or a batch of granular enzymes. A control aliquot without additive was always assayed simultaneously. After incubation at $37 \mathrm{C}$ for $6 \mathrm{hr}$, samples withdrawn at timed intervals were suspended in sodium dodecyl sulfate sample buffer $(1 \% 2$-mercaptoethanol, $2 \%$ sodium dodecyl sulfate, $80 \mathrm{~mm}$ Tris- $\mathrm{HCl}$ [pH 6.8], 10\% glycerol, and $0.05 \%$ bromphenol blue) and heated at $100 \mathrm{C}$ for $3 \mathrm{~min}$. They were electrophoresed on discontinuous slab gels, with $5 \%(\mathrm{wt} / \mathrm{vol})$ acrylamide in the stacking gel and $12.5 \%(\mathrm{wt} / \mathrm{vol})$ acrylamide in the resolving gel [17]. Labeled proteins were revealed by autoradiography (X-omat ${ }^{\circledR} \mathrm{S}$ film; Kodak S.A., Lausanne, Switzerland), with exposure at $-70 \mathrm{C}$ for two days. Molecular weights were determined by comparison with marker proteins from Sendai virus and vesicular stomatitis virus $[18,19]$ labeled with $\left[{ }^{35}\right.$ S]methionine.

Inhibition experiments. The effects of three inhibitors of serine proteases were tested on C3-cleaving activity and elastase-like activity of culture-positive pleural effusions and granular enzyme preparations. Phenyl methyl sulfonylfluoride $^{2}$ was purchased from Sigma Chemical Co., St. Louis, Mo. A peptide carbazate inhibitor [20] was provided by Merck Sharp and Dohme Research Laboratories, Rahway, N.J., and $\mathrm{N}$-ace-

\footnotetext{
2 See footnote 1.
} 
tyl-(Ala) $)_{4}$-chloromethylketone [21] was a gift from J. Powers, Georgia Institute of Technology, Atlanta.

In some experiments, $10 \%$ human serum mixed with $20 \mathrm{~mm}$ EDTA was used as an inhibitor; in others, samples of pleural fluids or granular enzymes were inactivated by heating at $80 \mathrm{C}$ for 10 min.

Preparation of bacterial sonicates and culture supernatants. Clinical isolates of Streptococcus pneumoniae, Streptococcus faecalis, group A $\beta$-hemolytic Streptococcus, Pseudomonas aeruginosa, Klebsiella pneumoniae, and Bacteroides fragilis were obtained by overnight culture in the appropriate medium. An average of $5 \times 10^{9}$ microorganisms was sedimented by centrifugation at $3,300 \mathrm{~g}$ for $15 \mathrm{~min}$, washed three times in Dulbecco's phosphate-buffered saline, and resuspended in $5 \mathrm{ml}$ of Dulbecco's phosphate-buffered saline without $\mathrm{Ca}^{++}$or $\mathrm{Mg}^{++}$. The bacteria were lysed by sonication (Sonifer ${ }^{\circledR ;}$; Branson, Danbury, Conn.) on crushed ice for $3 \mathrm{~min}$ (intensity, $50 \mathrm{~W}$ ). Residual intact bacteria and membranes were sedimented by centrifugation at $3,300 \mathrm{~g}$ for 15 min, and the supernatant was stored at $-20 \mathrm{C}$ until used (always within three days of preparation). There was a decrease in cfu of $>95 \%$ in all lysed bacterial preparations tested, assessed by serial dilution and plating of the preparations before and after sonication. The culture supernatant ( 5 $\mathrm{ml}$ ), which was obtained after the first sedimentation of the bacteria, was studied at the same concentration as the sonicate.

Complement studies. Complement studies were all carried out on EDTA-mixed fluids. C3 and $\beta-1 \mathrm{H}$ levels were measured by single radial immunodiffusion using monospecific antibodies to these proteins [22]. The results were expressed as a percentage of the levels in a pool of normal human plasma. C3d levels were quantitated in a two-step procedure [23]. In the first step, native $\mathrm{C} 3$ and the high-molecular-weight fragments $\mathrm{C} 3 \mathrm{~b}$ and $\mathrm{C} 3 \mathrm{c}$ were precipitated with polyethyleneglycol. Then the C3d level was measured in the polyethyleneglycol supernatant by single radial immunodiffusion with antiserum to $\mathrm{C} 3 \mathrm{~d}$. The results were expressed as a percentage of levels in an inulin-activated serum. The value for normal pooled human serum was $9.9 \%$.

Statistics. Results were expressed as means \pm SEM. C3-cleaving activity in culture-positive and culture-negative effusions was compared using the rank-sum test. Student's $t$-test was used to compare levels of complement components, protein concentrations, and leukocyte counts in infected and sterile pleural effusions.

\section{Results}

C3-cleaving activity. C3-cleaving activity was evaluated by incubating the EDTA-mixed supernatants of effusions from patients in group 1 and group 2 with ${ }^{125}$ I-labeled C3 bound to Sepharose (figure 1). The amount of $\mathrm{C} 3$ cleaved by culturepositive effusions increased with time, reaching a level of $18.4 \% \pm 7.3 \%$ (range, $0.9 \%-67.2 \%$ ), whereas culture-negative effusions cleaved only $2.4 \% \pm 0.9 \%$ of the labeled, bound C3 (range, $1.1 \%-3.4 \%)$ after incubation for $9 \mathrm{hr}(P<<$ 0.001 ). ${ }^{125}$ I-labeled C3 bound to Sepharose was incubated alone with each experiment as a control;

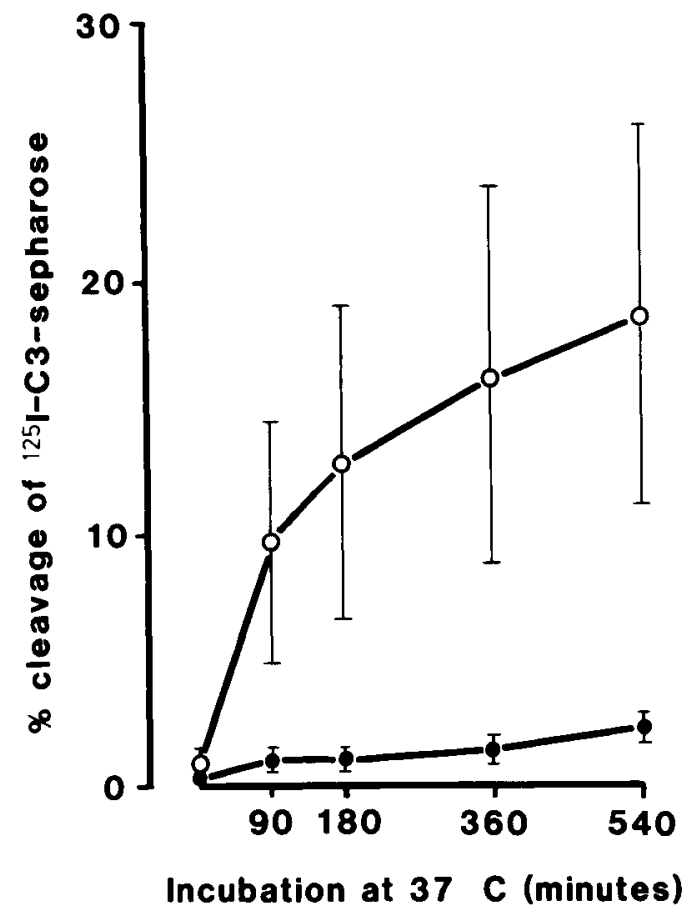

Figure 1. Percentage cleavage of ${ }^{125} \mathrm{I}$-labeled $\mathrm{C} 3$ bound to Sepharose by effusions from 10 patients with positive bacterial cultures $(O)$ and 19 patients with negative bacterial cultures $(\bullet)$. Labeled, bound C3 $(1.5 \times$ $10^{6} \mathrm{cpm}$ ) in $1.2 \mathrm{ml}$ of Dulbecco's phosphate-buffered saline, $\mathrm{pH} 7.3$, without $\mathrm{Ca}^{++}$and $\mathrm{Mg}^{++}$was incubated at 37 $C$ with $0.3 \mathrm{ml}$ of EDTA-mixed supernatant of pleural ef fusions, and timed sampling of $0.2-\mathrm{ml}$ aliquots was performed over $9 \mathrm{hr}$. The data are mean \pm SEM cpm in the supernatant $/ \mathrm{cpm}$ in the total sample $\times 100$. At $540 \mathrm{~min}$, the difference in cleavage was statistically significant $(P$ $<<0.001)$. 
Table 2. Cleavage of ${ }^{125}$ I-labeled $\mathrm{C} 3$ bound to Sepharose by sonicates of clinical bacterial isolates.

\begin{tabular}{lc}
\hline Microorganism & Percentage cleavage \\
\hline Klebsiella pneumoniae & 1.3 \\
Streptococcus faecalis & 2.3 \\
Streptococcus pneumoniae & 1.1 \\
Group A $\beta$-hemolytic Streptococcus & 1.0 \\
Pseudomonas aeruginosa & 1.3 \\
Staphylococcus aureus & 1.3 \\
Bacteroides fragilis & 1.3 \\
Mean \pm SEM & $1.4 \pm 0.2$
\end{tabular}

NOTE. Bacterial sonicates $(300 \mu$ ) corresponding to $1-2 \times$ $10^{8}$ lysed organisms were incubated for $24 \mathrm{hr}$ with ${ }^{125}$ I-labeled $\mathrm{C} 3$ bound to Sepharose $\left(1.5 \times 10^{6} \mathrm{cpm}\right)$ in $1.2 \mathrm{ml}$ of Dulbecco's phosphate-buffered saline, $\mathrm{pH} 7.3$, without $\mathrm{Ca}^{++}$and $\mathrm{Mg}^{++}$. Data are percentage of $\mathrm{cpm}$ in the supernatant/cpm added to the suspension for triplicate determinations.

spontaneous breakdown or release of iodine was only $0.3 \% \pm 0.2 \%$ over a 9 -hr period. Thus, significant cleavage of bound $\mathrm{C} 3$ was observed in the culture-positive group as compared with the culture-negative group. In further experiments, granular enzymes from PMNLs were incubated with 125 I-labeled C3 bound to Sepharose; cleavage of bound $\mathrm{C} 3$ occurred with similar kinetics to the reaction with effusions. After incubation for $9 \mathrm{hr}$, the granular enzyme preparation from $7 \times 10^{6}$ PMNLs (batch 3) cleaved $78.5 \%$ of ${ }^{125}$ I-labeled C3 bound to Sepharose. Cleavage was $34 \%$ at $90 \mathrm{~min}, 54 \%$ at $180 \mathrm{~min}$, and $70 \%$ at $360 \mathrm{~min}$ (data not shown).

In contrast to the C3-cleaving activity of culture-positive effusions and the granular enzyme preparation, none of seven bacterial sonicates cleaved bound $\mathrm{C} 3$ significantly more than did culture-negative (control) effusions (table 2). Even after incubation for $24 \mathrm{hr}$, only $1.4 \% \pm 0.2 \%$ (range, 1.0\%-2.3\%) of the ${ }^{125}$ I-labeled C3 bound to Sepharose was cleaved. No significant C3cleaving activity was observed with the culture supernatants except for that of $P$. aeruginosa, which cleaved $15 \%$ of the labeled, bound $\mathrm{C} 3$.

Enzymatic nature of C3-cleaving activity. To explore more precisely the mechanism responsible for C3 cleavage in empyemas, the cleavage of ${ }^{125}$ I-labeled C 3 bound to Sepharose by culturepositive effusions and PMNL granular enzymes (batch 1) was assessed in parallel at various temperatures and at different $\mathrm{pH}$ values of the reaction buffer. $\mathrm{C} 3$-cleaving activity was optimal at $37 \mathrm{C}$, compared with $20 \mathrm{C}, 10 \mathrm{C}$, and $4 \mathrm{C}$ (figure 2). C3-cleaving activity was greater at $37 \mathrm{C}$ in a
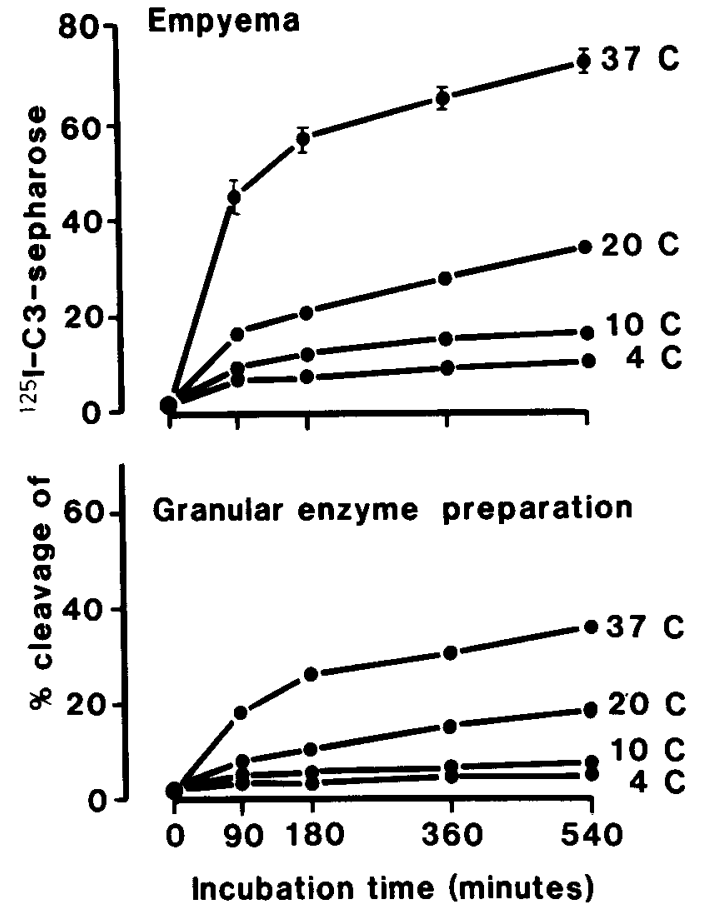

Figure 2. Percentage cleavage of ${ }^{125}$ I-labeled C3 bound to Sepharose by (top) a culture-positive pleural effusion from patient no. 2 and (bottom) a preparation (batch 1) of granular enzymes from normal human polymorphonuclear leukocytes. Labeled, bound C3 $(1.5 \times$ $10^{6} \mathrm{cpm}$ ) in $1.2 \mathrm{ml}$ of Dulbecco's phosphate-buffered saline, $\mathrm{pH} 7.3$, without $\mathrm{Ca}^{++}$and $\mathrm{Mg}^{++}$was incubated at various temperatures with $0.3 \mathrm{ml}$ of either EDTA-mixed supernatant of empyema or granular enzyme preparation without EDTA, and timed sampling of 0.2-ml aliquots was performed over $9 \mathrm{hr}$. The data for empyema tested at $37 \mathrm{C}$ are mean \pm SEM cpm in the supernatant/cpm in the total sample $\times 100$ for triplicate determinations.

buffer of $\mathrm{pH} 8.2$ than of $\mathrm{pH} 6$. These findings agree with those of Schmidt, ${ }^{3}$ who defined an optimal $\mathrm{pH}$ of 8 for granulocyte elastase when tested against a protein substrate.

The proteolytic nature of C3 cleavage by culture-positive effusions and preparations of PMNL granular enzymes was studied (figure 3). ${ }^{125}$ I-labeled C 3 bound to Sepharose was mixed with a culture-positive effusion and a granular enzyme preparation and incubated for $6 \mathrm{hr}$. Samples were tested by polyacrylamide gel electrophoresis at timed intervals for proteolytic breakdown, and the $\alpha$-chain and $\beta$-chain of $\mathrm{C} 3$ [8] were located in reference to the marker proteins. ${ }^{125}$ I-labeled C3 bound to Sepharose was also incubated alone as a control. In the mixtures of ${ }^{125}$ I-labeled $\mathrm{C} 3$ bound

\footnotetext{
${ }^{3}$ See footnote 1 .
} 


\begin{tabular}{|c|c|c|c|c|c|c|c|c|c|c|c|c|}
\hline \multirow[b]{2}{*}{$\begin{array}{l}\text { Incubation time } \\
\text { at } 37 \mathrm{C}(\mathrm{min})\end{array}$} & \multicolumn{4}{|c|}{ Granular enzymes } & \multicolumn{4}{|c|}{ Empyema } & \multicolumn{2}{|c|}{ C3 alone } & \multirow[t]{2}{*}{ SV } & \multirow[t]{2}{*}{ VSV } \\
\hline & 2 & 30 & 150 & 360 & 2 & 30 & 150 & 360 & 2 & 360 & & \\
\hline number & 1 & 2 & 3 & 4 & 5 & 6 & 7 & 8 & 9 & 10 & 11 & 12 \\
\hline
\end{tabular}

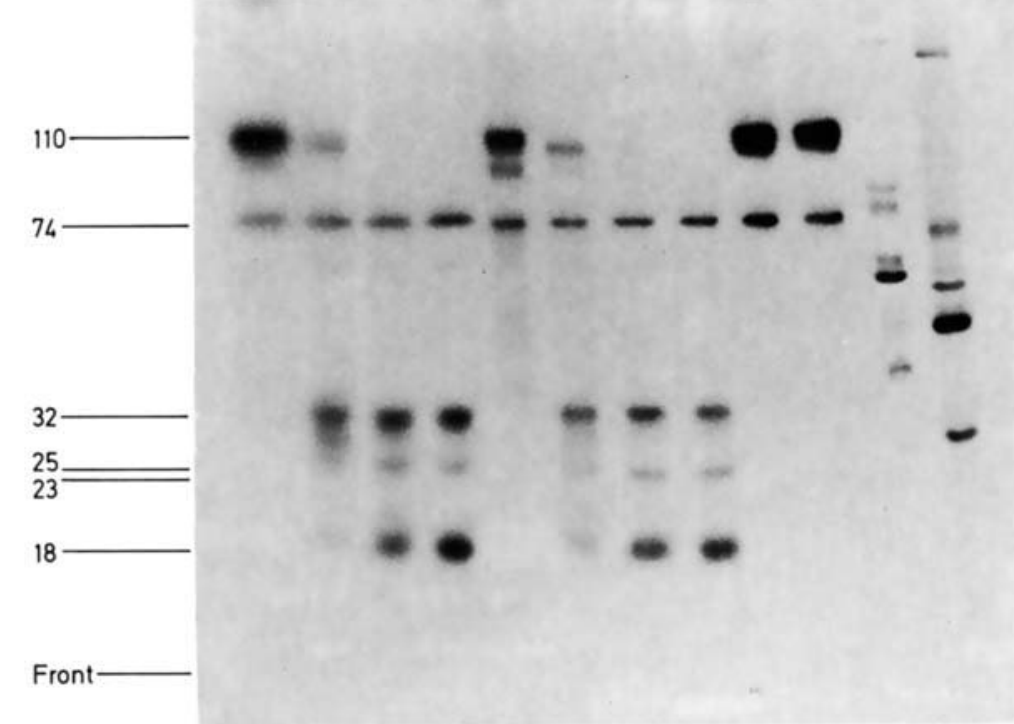

Figure 3. Autoradiogram after polyacrylamide gel electrophoresis of (lanes 1-4) $20 \mu \mathrm{l}$ of a granular enzyme preparation (batch 1) from normal human polymorphonuclear leukocytes and (lanes 5-8) $20 \mu \mathrm{l}$ of pleural empyema from a patient with positive bacterial cultures mixed with ${ }^{125}$ I-labeled C3 bound to Sepharose. Labeled, bound C3 was electrophoresed alone (lanes 9 and 10) as a control, and Sendai virus (lane 11) and vesicular stomatitis virus (lane 12) were used to determine molecular masses. The $\alpha$-chain and the $\beta$-chain of C3 appear at 110 and $74 \times 10^{3}$ daltons, respectively. The estimated molecular masses of the breakdown products of $\mathrm{C} 3$ are $32,25,23$, and 18 $\times 10^{3}$ daltons. to Sepharose with a granular enzyme preparation and with a culture-positive effusion, the amount of $\alpha$-chain decreased gradually as a function of length of incubation, while, simultaneously, breakdown products with smaller molecular masses appeared: 32,25 , and $18 \times 10^{3}$ daltons with the empyema and 32,23 , and $18 \times 10^{3}$ daltons with the granular enzymes. After incubation for 6 $\mathrm{hr}$, the amount of $\beta$-chain also slightly decreased. In contrast, none of these small breakdown products appeared in the control incubation. Thus, both the EDTA-mixed supernatant of the culturepositive effusion and the granular enzyme preparation have proteolytic activity on $\mathrm{C} 3$, particularly on its $\alpha$-chain.

To explore the nature of the $\mathrm{C} 3$-cleaving activity in empyema, we used human serum mixed with EDTA (final concentration, $20 \mathrm{~mm}$ ) as a source of $\alpha_{1}$-antitrypsin and $\alpha_{2}$-macroglobulin, the two natural inhibitors of PMNL granular enzymes in serum [24]. EDTA-mixed 10\% human serum was added to pleural effusions from patients no. 1 and no. 2 (with the highest $\mathrm{C} 3$-cleaving activity) in group 1 and to granular enzyme preparations, and the specimens were preincubated at room temperature (about $20 \mathrm{C}$ ) for $10 \mathrm{~min}$. When they were tested after incubation for $6 \mathrm{hr}$ at $37 \mathrm{C}$,
C3-cleaving activity was almost totally inhibited (table 3).

Elastase-like activity. Because the preceding results suggested that granulocyte elastase was a candidate for the neutral proteases responsible for breakdown of $\mathrm{C} 3[4,5,8]$, we tried to compare the C3-cleaving activity in empyema with that in a granular enzyme preparation using an elastasespecific substrate (TGP 928) and three inhibitors known to inhibit specifically serine proteases such as granulocyte elastase $[20,21] .{ }^{4}$ Elastase-like activity, as measured with the substrate TGP 928, could be detected in the granular enzyme preparations and all of the culture-positive effusions that cleaved $>18 \%$ of the ${ }^{125}$ I-labeled C 3 bound to Sepharose in our test. There was a linear correlation between the amount of C3-cleaving activity and the amount of elastase-like activity in the four samples of empyema that gave positive results with the assay for elastase-like activity and the two preparations of granular enzymes used (figure 4). No elastase-like activity was detected in the bacterial sonicates or in the culture supernatants.

Inhibition experiments. Phenyl methyl sulfonylfluoride $(2 \mathrm{~mm})$, a peptide carbazate in-

See footnote 1. 
hibitor (2.5 mM), and $\mathrm{N}$-acetyl-(Ala) $)_{4}$-chloromethylketone $(2.5 \mathrm{mM})$ were analyzed for their ability to inhibit the C3-cleaving activity and elastase-like activity of two culture-positive effusions and a granular enzyme preparation (table 3 ). The degree of inhibition ranged from $61 \%$ to $100 \%$. The peptide carbazate inhibitor and the chloromethylketone were more potent inhibitors of elastase-like activity than of C3-cleaving activity for both the granular enzyme preparation and the culture-positive effusions.

Concentrations of $\mathrm{C3}, \mathrm{C} 3 \mathrm{~d}$, and $\mathrm{\beta}-\mathrm{lH}$ in pleural fluids. Pleural effusions from patients in group 1 had a level of C3 of $45 \% \pm 9 \%$, of C $3 \mathrm{~d}$ of $80 \%$ $\pm 12 \%$, and of $\beta-1 \mathrm{H}$ of $97 \% \pm 29 \%$. In effusions of the control patients (group 2), the level of C3 was $34 \% \pm 6 \%$, of $\mathrm{C} 3 \mathrm{~d}$ was $25 \% \pm 6 \%$, and of $\beta-1 \mathrm{H}$ was $78 \% \pm 13 \%$. Between the two patient groups the levels of $\mathrm{C} 3$ and $\beta-1 \mathrm{H}$ were not significantly different, whereas levels of $\mathrm{C} 3 \mathrm{~d}$ were significantly higher in the culture-positive group than in the culture-negative group $(P<0.02)$.

\section{Discussion}

The most significant finding of the present study is the demonstration of an enzymatic activity that cleaved $\mathrm{C} 3$ in pleural effusions from patients with empyema, whereas culture-negative effusions of various etiologies were devoid of such activity. The breakdown of $\mathrm{C} 3$ through activation of the classical and/or the alternative pathways of complement as a trivial explanation of our findings was eliminated because the experiments were performed in the absence of divalent cations. The enzymatic nature of the C3-cleaving activity was substantiated by its temperature-dependence, its destruction by heat, and its inhibition by the addition of EDTA-mixed 10\% normal human serum as a source of the natural inhibitors $\alpha_{1}$-antitrypsin and $\alpha_{2}$-macroglobulin [24].

We have tried to assign the origin of this enzymatic activity either to bacteria or to PMNLs by, respectively, studying bacterial sonicates from a variety of strains which are classically isolated as the causative agents of empyema and a granular enzyme preparation of human PMNLs. None of the bacterial sonicates cleaved C3 significantly, whereas activities of the granular enzyme preparations and culture-positive effusions were similar: the time curves and the optimal $\mathrm{pH}$ for cleavage with the same amount of substrate were essentially the same. It is conceivable that a proteolytic enzyme of bacterial origin contributed to $\mathrm{C} 3$ cleavage in the effusions of patients no. 2 and no. 5 , from whom $P$. aeruginosa was isolated. This

Table 3. Characterization of C3-cleaving activity in pleural empyema and preparations of granular enzymes from normal human polymorphonuclear leukocytes.

\begin{tabular}{|c|c|c|c|c|c|c|}
\hline \multirow[b]{3}{*}{ Inhibitor } & \multicolumn{6}{|c|}{ Inhibition $(\%)$ of } \\
\hline & \multicolumn{3}{|c|}{ C3-cleaving activity } & \multicolumn{3}{|c|}{ Elastase-like activity } \\
\hline & $\begin{array}{l}\text { Empyema } \\
\text { no. } 1\end{array}$ & $\begin{array}{l}\text { Empyema } \\
\text { no. } 2\end{array}$ & $\begin{array}{l}\text { Granular } \\
\text { enzymes }\end{array}$ & $\begin{array}{c}\text { Empyema } \\
\text { no. } 1\end{array}$ & $\begin{array}{c}\text { Empyema } \\
\text { no. } 2\end{array}$ & $\begin{array}{l}\text { Granular } \\
\text { enzymes }\end{array}$ \\
\hline $\begin{array}{l}\text { Human serum }(10 \%)+\text { EDTA } \\
\quad(20 \mathrm{~mm})\end{array}$ & 97 & 98 & 98 & 100 & 100 & 90 \\
\hline $\begin{array}{l}\text { Phenyl methyl sulfonylfluoride } \\
(2 \mathrm{~mm})\end{array}$ & 77 & 96 & 99 & 80 & 100 & 80 \\
\hline $\begin{array}{l}\text { Peptide carbazate inhibitor } \\
(2.5 \mathrm{~mm}) \\
\text { Chloromethylketone }(2.5 \mathrm{~mm})\end{array}$ & $\begin{array}{l}80 \\
66\end{array}$ & $\begin{array}{l}69 \\
62\end{array}$ & $\begin{array}{l}64 \\
61\end{array}$ & $\begin{array}{l}90 \\
70\end{array}$ & $\begin{array}{l}97 \\
69\end{array}$ & $\begin{array}{l}94 \\
90\end{array}$ \\
\hline
\end{tabular}

NOTE. C3-cleaving activity and its inhibition were quantitated by incubation of $40 \mu$ l of granular enzyme preparation or pleural effusion (from patient no. 1 or no. 2) in $200 \mu \mathrm{l}$ of Dulbecco's phosphate-buffered saline (pH 7.3) without $\mathrm{Ca}^{++}$or $\mathrm{Mg}^{++}$containing $200,000 \mathrm{cpm}$ of ${ }^{125}$ I-labeled C3 bound to Sepharose for $6 \mathrm{hr}$ with and without inhibitor. The empyema specimens and granular enzymes were preincubated with the inhibitor for $10 \mathrm{~min}$ at room temperature (about $20 \mathrm{C}$ ) and then incubated at $37 \mathrm{C}$ except for chloromethylketone and peptide carbazate inhibitor (Merck Sharp and Dohme Research Laboratories, Rahway, N.J.), which were tested at room temperature. Elastase-like activity was tested at room temperature in $1-\mathrm{ml}$ samples of $0.5 \mathrm{~m}$ phosphate buffer ( $\mathrm{pH}$ 7.5) containing $100 \mu \mathrm{l}$ of empyema or granular enzymes. The substrate succinyl-Ala-Ala-Pro-7-amino-methyl-coumarin (TGP 928) was added (final concentration, $10^{-3} \mathrm{M}$ ), and each sample was tested with or without inhibitor. The samples were preincubated with the inhibitor as described above. Inhibition is expressed as 100 - ([activity of sample with inhibitor/activity of sample without inhibitor] $\times 100$ ). 


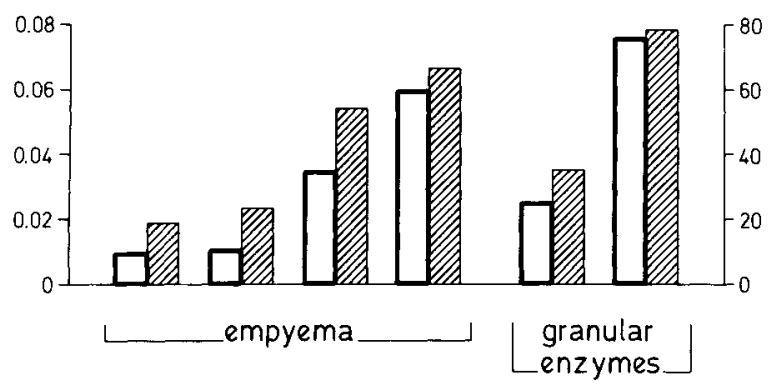

Figure 4. Linear correlation between C3-cleaving activity $(\square)$ and elastase-like activity $(\square)$ in two batches of granular enzymes from normal human polymorphonuclear leukocytes and four samples of pleural empyema from patients with positive bacterial cultures with elastase-like activity. C3-cleaving activity is given as percentage cleavage of ${ }^{125}$ I-labeled $\mathrm{C} 3$ bound to Sepharose after incubation for $9 \mathrm{hr}$ at $37 \mathrm{C}$, and elastase-like activity is given as change in $\mathrm{OD}$ at $360 \mathrm{~nm}$ over a 4-min period with the substrate succinyl-Ala-AlaPro-7-amino-4-methyl-coumarin (TGP 928).

microorganism is known to secrete a proteolytic enzyme that cleaves $C 3$ and other complement components [25]. However, patient no. 2 had a very high $\mathrm{C} 3$-cleaving activity $(67 \%)$, whereas the amount of enzyme secreted under optimal conditions by $1-2 \times 10^{8} P$. aeruginosa cleaved only $15 \%$ of the labeled, bound C3. In addition, the effusion from patient no. 2 had the highest elastaselike activity observed, whereas the culture supernatant of $P$. aeruginosa had no detectable activity on this substrate. The effusion from patient no. 5 had no elastase-like activity and a C3-cleaving activity of $5.8 \%$. An elastase-like activity could be demonstrated by means of an elastase-specific, synthetic substrate in some of the most "active" culture-positive effusions, and a correlation of C3-cleaving and elastase-like activity was observed in these cases. Both C3-cleaving and elastase-like activities were inhibited by EDTA-mixed $10 \%$ normal human serum and by three serine protease inhibitors. The peptide carbazate inhibitor and the chloromethylketone are considered to be specific inhibitors of granulocyte elastase [20,21]. In both systems tested-that is, granular enzymes and culture-positive effusions - these two compounds were more potent inhibitors of elastase-like activity than of the C3-cleaving activity. There are two possible explanations for these findings. First, both inhibitors may be more efficient inhibitors of the esterolytic activity (TGP 928 is an ester substrate) than of the proteolytic activity (with $\mathrm{C} 3$ as substrate) of the enzyme(s). Alternatively, the residual C3-cleaving activity may reflect the proteoly- tic activity of other granular enzymes such as cathepsin $\mathrm{G}$.

The results of our experiments therefore suggest that elastase is one of the proteases involved in the cleavage of C3. Indeed, elastase and collagenase are present in large amounts in granulocytes, representing $\sim 5 \%$ of the dry weight of the cell [26], in comparison to cathepsin G, which is present in much smaller quantities. Elastase and cathepsin $G$ are located in the primary granules and collagenase in the secondary granules of granulocytes [27]. Upon phagocytosis, these granules, in addition to fusing intracellularly with the phagosome, may be released into the surrounding medium $[26,28]$. Thus, it is conceivable that these enzymes may be detected extracellularly in a purulent infection with high bacterial concentrations, such as empyema. Three neutral proteases from PMNLs have been shown to cleave C3 in vitro $[4,5,8]$ : elastase, collagenase, and cathep$\sin$ G. Collagenase is calcium-dependent and inhibited by EDTA [26]; it cannot be involved in the C3-cleaving activity of our culture-positive pleural effusions because all experiments were carried out in the absence of $\mathrm{Ca}^{++}$. Cathepsin $\mathrm{G}$ may be partly responsible for the $\mathrm{C} 3$-cleaving activity observed in our tests, despite the fact that this enzyme has only minimal activity on the elastase-specific substrate used in our experiments. Another enzyme, present in the cytosol of PMNLs, is the plasminogen activator described by GranelliPiperno et al. [29]; the activity of this enzyme can only be detected if cell lysates are prepared in the presence of elastase inhibitors, presumably because it is otherwise exposed to proteolytic degradation by elastase. Because we detected elastase-like activity in several culture-positive effusions, the plasminogen activator was probably destroyed.

The pattern of proteolysis of $\mathrm{C} 3$ could be further established by polyacrylamide gel electrophoresis for both a culture-positive effusion and granular enzymes (figure 3 ). The pattern of the breakdown products obtained in our experiments indicates that the cleavage of the molecule $\mathrm{C} 3$ proceeds beyond cleavage in $\mathrm{C} 3 \mathrm{a}$ and $\mathrm{C} 3 \mathrm{~b}$, both fragments with biologic activity. The fragments observed in our experiments had molecular masses of $32,25,23$, and $18 \times 10^{3}$ daltons. The presence of these small fragments and the simultaneous disappearance of the $\alpha$-chain indicate that, at the end of the incubation period of $6 \mathrm{hr}$, no C $3 \mathrm{~b}$ was present 
(this fragment has a molecular mass estimated at $180 \times 10^{3}$ daltons) [3].

That high levels of C3d in culture-positive effusions were found in two other studies of empyema $[1,30]$ further supports the proposal of increased breakdown of $\mathrm{C} 3$ in empyema. Because, according to Taylor et al. [8], uncontrolled digestion of C3 with granulocyte elastase also leads to a fragment similar to $\mathrm{C} 3 \mathrm{~d}$, it can be postulated that these high levels of C3d reflect not only complement-mediated breakdown of $\mathrm{C} 3$ but also the action of granulocyte elastase.

No significant difference in the levels of $\mathrm{C} 3$ and $\beta-1 \mathrm{H}$ could be found between effusions from patients in group 1 and group 2 . The lack of difference in $\mathrm{C} 3$ levels between the two groups may be explained by the cross-reaction of breakdown products of $\mathrm{C} 3$ with antibody and thus may not reflect biologically active $\mathrm{C} 3$. This suggestion is supported by the finding of Lew et al. [1] that, despite the presence of high levels of immunoreactive $\mathrm{C} 3$, levels of total hemolytic complement were low in empyema specimens.

In earlier reports conversion of $\mathrm{C} 3$ and $\mathrm{C} 5$ by neutral proteases in vitro has been demonstrated in conditions where $\alpha_{1}$-antitrypsin and $\alpha_{2}$-macroglobulin were absent [5-8]. When measured in serum [4], conversion of C3 and C5 by elastase and collagenase did not occur until the molar ratio of the enzyme to the inhibitor was $>1$. Our demonstration of $\mathrm{C} 3$ cleavage in empyema clearly indicates that the inhibitor potential of empyema samples is too low to inactivate all of the enzyme present. This explanation is further supported by the fact that enzymatic activity in empyema fluid was almost totally abolished when EDTA-mixed $10 \%$ normal human serum was added. What are the possible mechanisms influencing the inhibitor concentration in the pleural space? Insufficient influx or synthesis in the infected pleural space may be one explanation. Another is that bacteria might be implicated in the reduction of the local inhibitor potential. Indeed, $P$. aeruginosa and Proteus mirabilis, both of which are occasionally recovered from the pleural space, have been observed to destroy $\alpha_{1}$-antitrypsin [31, 32]. It may be that these bacteria, as well as other species of bacteria, might destroy this inhibitor in empyema specimens.

The finding of a "permissive" environment for the activity of neutral proteases from PMNLs in pleural empyema suggests that a broad spectrum of substrates may be considered as potential targets for these enzymes. Among the important factors responsible for humoral immunity, IgG and IgM are known to be cleaved by elastase in vitro $[11,12]$. Also, previous work has shown that ${ }_{125}$ I-labeled IgG was hydrolyzed by empyema fluids and that levels of $\operatorname{IgG}$ and $\operatorname{IgM}$ in these fluids were low [30].

In conclusion, the present study describes the presence of a C3-cleaving enzymatic activity in empyema. Our results show that the local inhibitor potential in empyema is too low to inactivate the C3-cleaving activity. This activity is not identical with that of complement-derived enzymes, and its characteristics are very similar to those of granular enzymes from human granulocytes. From studies of substrate and inhibitor specificity, we conclude that granulocyte elastase is one of the granular enzymes involved in the complementindependent $\mathrm{C} 3$ cleavage. Because complementmediated opsonic activity has been shown to be strikingly reduced in empyema [1] and because the enzymatic activity described in the present study promotes a thorough breakdown of $\mathrm{C} 3$, an insufficient quantity of $\mathrm{C} 3 \mathrm{~b}$, the biologically active compound of $\mathrm{C} 3$, may be one of the consequences of this enzymatic activity. Therefore, the coating of microorganisms with $\mathrm{C} 3 \mathrm{~b}$ could be deficient. In turn, this result could impair their recognition by PMNLS and thus be one of the factors conducive to the persistence of bacteria in empyema.

\section{References}

1. Lew, P. D., Zubler, R., Vaudaux, P., Farquet, J. J., Waldvogel, F. A., Lambert, P.-H. Decreased heat-labile opsonic activity and complement levels associated with evidence of $\mathrm{C} 3$ breakdown products in infected pleural effusions. J. Clin. Invest. 63:326-334, 1979.

2. Fearon, D. T., Austen, K. F. The alternative pathway of complement - a system for host resistance to microbial infection. N. Engl. J. Med. 303:259-263, 1980.

3. Harrison, R. A., Lachmann, P. J. The physiological breakdown of the third component of human complement. Mol. Immunol. 17:9-20, 1980.

4. Johnson, U., Ohisson, K., Olsson, I. Effects of granulocyte neutral proteases on complement components. Scand. J. Immunol. 5:421-426, 1976.

5. Venge, P., Olsson, I. Cationic proteins of human granulocytes. IV. Effects of the complement system and mediation of chemotactic activity. J. Immunol. 115:15051508,1975 .

6. Brozna, J. P., Senior, R. M., Kreutzer, D. L., Ward, P. A. Chemotactic factor inactivators of human granulocytes. J. Clin. Invest. 60:1280-1288, 1977.

7. Goldstein, I. M., Weissmann, G. Generation of C5-derived 
lysosomal enzyme-releasing activity (C5a) by lysates of leukocyte lysosomes. J. Immunol. 113:1583-1588, 1974.

8. Taylor, J. C., Crawford, I. P., Hugli, T. E. Limited degradation of the third component (C3) of human complement by human leukocyte elastase (HLE): partial characterization of C3 fragments. Biochemistry 16:3390-3396, 1977.

9. Egbring, R., Schmidt, W., Fuchs, G., Havemann, K. Demonstration of granulocytic proteases in plasma of patients with acute leukemia and septicemia with coagulation defects. Blood 49:219-231, 1977.

10. Starkey, P. M., Barrett, A. J., Burleign, M. C. The degradation of articular collagen by neutrophil proteinases. Biochim. Biophys. Acta 483:386-397, 1977.

11. Prince, H. E., Folds, J. D., Spitznagel, J. K. Proteolysis of human IgG by human polymorphonuclear leukocyte elastase produces an $\mathrm{Fc}$ fragment with in vitro biological activity. Clin. Exp. Immunol. 37:162-168, 1979.

12. Prince, H. E., Folds, J. D., Spitznagel, J. K. Interaction of human polymorphonuclear leukocyte elastase with human IgM. In vitro production of an Fab $\mu$-like fragment. Mol. Immunol. 16:301-306, 1979.

13. Böyum, A. Isolation of mononuclear cells and granulocytes from human blood. Isolation of mononuclear cells by one centrifugation, and of granulocytes by combining centrifugation and sedimentation at $1 \mathrm{~g}$. Scand. J. Clin. Lab. Invest. 21(Suppl. 97):77-89, 1968.

14. Baggiolini, M. The isolation of granules from neutrophil polymorphonuclear leukocytes (PMN's). Methods Enzymol. 31:345-353, 1974.

15. Tack, B. F., Prahl, J. W. Third component of human complement: purification from plasma and physiochemical characterization. Biochemistry 15:4513-4521, 1976.

16. McConahey, P. J., Dixon, F. J. A method of trace iodination of proteins for immunologic studies. Int. Arch. Allergy Appl. Immunol. 29:185-189, 1966.

17. Laemmli, U. K. Cleavage of structural proteins during the assembly of the head of bacteriophage T4. Nature 227:680-685, 1970.

18. Lamb, R. A., Mahy, B. W. J., Choppin, P. W. The synthesis of Sendai virus polypeptides in infected cells. Virology 69:116-131, 1976.

19. Wagner, R. R., Prevec, L., Brown, F., Summers, D. F., Sokol, F., MacLeod, R. Classification of rhabdovirus proteins: a proposal. J. Virol. 10:1228-1230, 1972.

20. Dorn, C. P., Zimmerman, M., Yang, S. S., Yurewicz, E. C., Ashe, B. M., Frankshun, R., Jones, H. Proteinase inhibitors. I. Inhibitors of elastase. J. Med. Chem. 20:1464-1468, 1977.

21. Powers, J. C., Gupton, B. F., Harley, A. D., Nishino, N., Whitley, R. J. Specificity of porcine pancreatic elastase, human leukocyte elastase and cathepsin G: inhibition with peptide chloromethyl ketones. Biochim. Biophys. Acta 485:156-166, 1977.

22. Perrin, L. H., Lambert, P. H., Nydegger, U. E., Miescher, P. A. Quantitation of C3PA (properdin factor B) and other complement components in diseases associated with a low $\mathrm{C} 3$ level. Clin. Immunol. Immunopathol. 2:16-27, 1973.

23. Perrin, L. H., Lambert, P. H., Miescher, P. A. Complement breakdown products in plasma from patients with systemic lupus erythematosus and patients with membranoproliferative or other glomerulonephritis. J. Clin. Invest. 56:165-176, 1975.

24. Ohlsson, K. $\alpha_{1}$-Antitrypsin and $\alpha_{2}$-macroglobulin. Interactions with human neutrophil collagenase and elastase. Ann. N.Y. Acad. Sci. 256:409-419, 1975.

25. Schultz, D. R., Miller, K. D. Elastase of Pseudomonas aeruginosa: inactivation of complement components and complement-derived chemotactic and phagocytic factors. Infec. Immun. 10:128-135, 1974.

26. Smolen, J. E., Weissman, G. The granulocyte: metabolic properties and mechanisms of lysosomal enzyme release. In K. Havemann and A. Janoff [ed.]. Neutral proteases of human polymorphonuclear leukocytes: biochemistry, physiology and clinical significance. Urban and Schwarzenberg, Baltimore, 1978, p. 56-76.

27. Baggiolini, M., Schnyder, J., Bretz, U. Lysosomal enzymes and neutral proteinases as mediators of inflammation. Advances in Inflammation Research 1:263-272, 1979.

28. Stossel, T. P. Phagocytosis [part 2]. N. Engl. J. Med. 290:774-780, 1974.

29. Granelli-Piperno, A., Vassalli, J.-D., Reich, E. Secretion of plasminogen activator by human polymorphonuclear leukocytes: modulation by glucocorticoids and other effectors. J. Exp. Med. 146:1693-1706, 1977.

30. Lew, D. P., Despont, J.-P., Perrin, L. H., Aguado, M.-T., Lambert, P. H., Waldvogel, F. A. Demonstration of a local exhaustion of complement components and of an enzymatic degradation of immunoglobulins in pleural empyema: a possible factor favouring the persistence of local bacterial infections. Clin. Exp. Immunol. 42:506-514, 1980.

31. Moskowitz, R. W., Heinrich, G. Bacterial inactivation of human serum alpha-1 antitrypsin. J. Lab. Clin. Med. 77:777-785, 1971.

32. Morihara, K., Tsuzuki, H., Oda, K. Protease and elastase of Pseudomonas aeruginosa: inactivation of human plasma $\alpha_{1}$-proteinase inhibitor. Infec. Immun. 24:188193, 1979. 